\title{
A LA ESCUCHA DE UN PAISAJE ACÚSTICO EN LAS CRÓNICAS DE JOSÉ DONOSO*
}

\author{
LISTENING TO AN ACOUSTIC LANDSCAPE \\ IN JOSÉ DONOSO’S CHRONICLES
}

\author{
Andrés Ferrada Aguilar \\ Universidad de Playa Ancha, Valparaíso, Chile \\ aferrada@upla.cl
}

\begin{abstract}
Resumen: El presente estudio se centra en una selección de crónicas de José Donoso publicadas a inicios de los ochenta. En estos trabajos se observa la enunciación de un paisaje urbano que, sin ignorar por completo un orden ocular, adopta una decidida figuración acústica. La ciudad de Santiago, en tanto referente visible, suscita fantasías y una disposición a la escucha que enfatiza imágenes acústicas y la imaginación literaria del cronista.
\end{abstract}

Palabras clave: Crónicas del retorno, giro acústico, paisaje urbano y acústico, enunciación.

\begin{abstract}
This study focuses on a selection of chronicles by José Donoso published at the beginning of the 1980s. Without totally ignoring the ocular order, these works evince the enunciation of an urban landscape that critically adopts an acoustic figuration. The city of Santiago, as a visible referent, awakes fantasies in a hearing disposition that emphasizes aural images as well as the chronicler's literary imagination.
\end{abstract}

Keywords: Homecoming chronicles, acoustic turn, acoustic and urban landscape, enunciation.

Recibido: 31.07.2017. Aceptado: 20.05.2018.

\footnotetext{
* Este trabajo se enmarca en el Proyecto FONDECYT de Iniciación a la Investigación $\mathrm{N}^{\circ} 11150158$, del cual soy investigador responsable.
} 


\section{Introducción}

I pudiésemos establecer una cualidad atribuible a la producción cronística de José Donoso (1924-1996), ese rasgo sería la versatilidad, incluso tratándose de una zona más específica como el de sus crónicas urbanas. Esta variación circula sobre temas que van desde una crítica de la vida cotidiana hasta la fisonomía estética de la ciudad de Santiago. Pero no solo eso. La disposición porosa del cuerpo del cronista, es decir la donación sensible que permite el registro escritural de la ciudad y sus paisajes, revela el concurso de diversos regímenes perceptuales. Quizás el más evidente dice relación con la visualidad. Relativizo este punto porque, me parece, aún existen intersticios visuales inexplorados en la obra del autor ${ }^{1}$. Otro afluente, el locomotor, hará que Donoso, "paseando muy lento", se pierda en "esta esponja ávida que ha ido dejando despoblado el resto del inmenso país" (1998: 205). Una tercera forma de interacción con la ciudad es de orden acústico, que problematiza los regímenes anteriores, los temas que atraviesan la obra del autor y la enunciación del paisaje urbano. De aquí se desprenden imágenes y representaciones paisajistas que revelan, en el plano de la enunciación, una subjetividad que crea una composición acústica de la ciudad de Santiago. A continuación ofrecemos consideraciones fundamentales del estado del arte en torno a nuestro objeto de estudio.

En la actualidad, los enfoques sobre el paisaje y sus representaciones, entre ellas la literatura, conllevan transformaciones significativas. Sobresalen teorías y prácticas discursivas donde el paisaje deja de estar sometido al arbitrio racionalista de saberes cartesianos. El acento cae en aproximaciones al paisaje de tipo "monista" (Urquijo y Barrera, 2009: 227) que intentan des-jerarquizar el "dualismo hombre/naturaleza, típico del naturalismo del pensamiento moderno" (Besse, 2006: 158). Se priorizan, en consecuencia, las múltiples experiencias del paisaje urbano, como por ejemplo su "legibilidad semiótica" (Nogué, 2007: 21)². De lo anterior cons-

${ }^{1}$ Un aspecto a considerar radica en las relaciones que se establecen entre una mirada al paisaje urbano, entendida como postura de enunciación con un sesgo particular e idiosincrásico, y la traducción no solo visual, sino también imaginada, de este enfoque en el espacio literario de las crónicas de José Donoso.

${ }^{2}$ Otros autores que privilegian este giro en las miradas al paisaje son Marta Llorente, Javier Maderuelo, Raffaele Milani y Alain Roger. Sobre los aspectos teóricos del paisaje, agradezco la valiosa colaboración bibliográfica de Mario Ferrada Aguilar, arquitecto y académico de la Facultad de Arquitectura y Urbanismo, Universidad de Chile. 
tatamos una orientación integrativa hacia el paisaje en distintos campos disciplinares. La geografía humana, por ejemplo, enfatiza la configuración del paisaje a partir de componentes físicos, contenidos culturales, y vivencias y percepciones (Martínez de Pisón, 2009).

Nuestro enfoque al paisaje destaca estas transformaciones, pero conscientes de que no son definitivas, ni tampoco señalan un umbral omnicomprensivo en torno a las emergencias paisajistas. No podría ser de otro modo. Concebido como la proyección de una subjetividad que lo transita y modela (Solnit, 2015: 21-25), el paisaje compromete una relación sensible con la ciudad en momentos de intensidad psíquica y estética (Milani, 2007: 63-66). Por lo mismo, y traspasando los bordes de su visibilidad semiótica, optamos por pensar el paisaje urbano en tanto emergencia, es decir, como un espacio experiencial donde confluyen prácticas citadinas, intercambios polisensoriales y figuraciones subjetivadas del entorno.

Este punto de entrada es pertinente con una acústica que repercute y tensiona la enunciación del paisaje en las crónicas de José Donoso. Al respecto, el trabajo señero del músico Murray Schafer vierte reflexiones sobre el paisaje sonoro, "soundscape", que describe en términos de ambientes generadores de eventos que se escuchan (1994: 4-5). Schafer explora la posibilidad de una ecología acústica, búsqueda que le lleva a plantear una "clariaudiencia" (10) como modo de resistir la contaminación acústica en las urbes contemporáneas. Los alcances del paisaje sonoro han adoptado importantes variaciones desde la década del setenta, como indican los trabajos de Adrianne Janus y Jean-Luc Nancy que revisaremos en el marco conceptual. Los ambientes sonoros se problematizan en concordancia con los enfoques contemporáneos al paisaje, y en el contexto de un giro epistémico "anti-ocular".

En nuestro estudio, observamos que el interés de Donoso no se dirige a la manifestación física y/o exterior del sonido, sino al momento crítico en que los referentes urbanos se trizan acústicamente al interior de su subjetividad. La labor interpretativa de quien escucha es fundamental. Escuchar equivale, por lo tanto, a un acto creador que metaforiza e imagina la ciudad de Santiago a partir de la emergencia de un paisaje acústico interiorizado. Este paisaje, lejos de promover una audición/interpretación prístina del entorno, insta opacidades y excedentes de sentido, necesarios para una productiva indeterminación literaria (Ricoeur, 1995). Esta opacidad nos 
remite también a las expresiones auráticas en la crítica de Walter Benjamin, como los objetos naturales, caracterizados por su ingobernabilidad y la "manifestación irrepetible de su lejanía" (1989: 24).

Enfoques recientes en torno al paisaje en la literatura chilena han adquirido matices que abordan las complejidades del fenómeno en perspectivas interdisciplinares. Uno de estos trabajos es Cartografía de José Donoso (2004). Si bien su autor, Pablo Catalán, no aborda el problema del paisaje directamente, instala pistas para su comprensión en la narrativa donosiana a partir de "un juego de espacios" y "un arte de los límites". En efecto, se señala que Donoso posee "una voluntad de arte" que le impulsa a "una escritura que supere todos los límites, y las limitaciones, de la tradición chilena, y encontrar una línea capaz de abrir su punto de fuga" (190). Desde este arte de los límites, nuestro trabajo escuchará con atención cómo el paisaje acústico advierte el inicio de ese desgarro escritural en las crónicas de José Donoso.

Otro estudio de interés es Ciudades (in)ciertas (2009), por cuanto encarece imaginarios y poéticas urbanas en una producción discursiva amplia: novelas, ensayos, poesía y crónicas. Sus editores señalan que "los espacios residuales [de una ciudad] se ofrecen a la actividad de la conciencia imaginal en la literatura, cobrando ésta una importancia decisoria en la construcción de los imaginarios del lugar" (13). Creemos que estos imaginarios potencian y, al mismo tiempo, se transforman a la luz estética y cultural de los paisajes urbanos.

Finalmente, un trabajo que específicamente recoge la mirada del paisaje en la escritura de Donoso es el de Sebastián Schoennenbeck, José Donoso. Paisajes, rutas y fugas (2015). Interesa la postura del autor respecto a los efectos visuales en la obra de Donoso, en particular a través de Casa de campo (1978), novela que le permite esgrimir una definición de paisaje. Concluye en el capítulo dedicado a esta narración que a "través de referencias pictóricas, la imitación paisajística donosiana nos permite entrever las [...] soldaduras escenográficas con las cuales se fabrica una naturaleza que, en definitiva, nada tiene de natural" (86). Nuestra indagación, por su parte, ofrece un giro doble en cuanto a la obra donosiana: se centra en sus crónicas urbanas y, desde aquí, en los hitos citadinos que suscitan paisajes acústicos subjetivados. 
Proponemos que la figuración del régimen acústico en las crónicas remite, siguiendo la imagen derivativa del eco, a un paisaje urbano que ha desaparecido, o cuya existencia se ciñe a un porvenir y a la audición deseosa del cronista. Los sonidos despiertan, en otras palabras, un anhelo por hitos que han sido anulados o degradados por una "oligarquía contemporánea” (Donoso, 1998: 209). A diferencia de los recorridos oculares o táctiles, el sondeo de la ciudad de Santiago se amplifica más allá de los estímulos o contingencias físicas. Siguiendo esta vía, la experiencia acústica sobrepasa su impronta sensible en la trama espacio-temporal y deja entrever, o entreescuchar, una música ausente. Esta composición, metáfora de "un mito poético" (Donoso, 1998: 156) que la ciudad de Santiago aún no consolida, deviene contrapartida de un espacio urbano que la subjetividad del autor traduce como un paisaje silente y homogéneo. Con el fin de "escuchar" estos paisajes en la escritura donosiana, hemos seleccionado un conjunto de crónicas reunidas en Artículos de incierta necesidad (1998) y José Donoso. Diarios, ensayos, crónicas (2009): "Idioma y retorno" (1981), "Voz e inventario" (1983), "Los barrios bajos de Santiago" (1982) y "De mis tías, la más bella" (1982).

El soporte conceptual de este estudio sigue tres aspectos interrelacionados: la emergencia de un espacio acústico, la percepción de un paisaje urbano silente y la recomposición de la subjetividad. Indicaremos los alcances de estos ejes para establecer el modo en que ellos entran en juego en la discusión de las crónicas. En el ensayo A la escucha (2007), el filósofo Jean-Luc Nancy problematiza los enlaces entre la visión y la escucha. El acento migra de la relación sinestésica entre estas dimensiones hacia el estupor que la escucha efectúa en el sujeto. Así, "estar a la escucha será siempre estar tendido hacia o en un acceso al sí mismo-deberíamos decir, de un modo patológico, un acceso de sí: ċel sentido-sonoro-no será ante todo y en cada oportunidad una crisis de sí?" (25). La audición afecta no solo la sensibilidad o la inclinación sensorial del sujeto al mundo, sino algo más, que no es a fuerza "todo su ser". Reticente a la naturalización de la identidad, José Donoso adscribe a un espacio literario “donde medra la emoción del autor" (1998: 115) y donde, en nuestro argumento, los sonidos ofrecen al sujeto descentrado nuevas vías de enmascaramiento. "Escuchar es aguzar el oído", advierte Nancy, "una intensificación y una preocupación, una curiosidad o una inquietud" (16). 
En la percepción del paisaje, la escucha comporta un interés que inclina el oído donosiano a sonidos que delatan una ausencia, o la desaparición de una forma literaria de construir ciudad. Moviliza ecos de un mito poético que Santiago no ha logrado aquilatar, a diferencia de otras capitales latinoamericanas, como Buenos Aires, donde este mito gozaría de perfecta salud (Donoso, 1998: 156-57). Próximo a estas ausencias, el oído del autor y, desde este canal, su subjetividad, se fracturan y "corren el riesgo", de acuerdo a Julio Ramos, "de perder la ruta, de pasar a la herejía, a la psicosis o, en los casos aparentemente más benévolos, a la excentricidad de la poesía o de las novelas 'polifónicas"' (2015: 231). El texto Haschisch de Walter Benjamin es indispensable para el planteamiento de Ramos. Según este último la historia no siempre es capaz de transmitir "el momento cuando 'la intensidad de la impresión acústica elimina todas las demás' [...], palabras que se permite usar Walter Benjamin al recordar el paseo nocturno por las orillas de la ciudad portuaria [de Marsella], que lo condujo a experimentar, por primera vez, el vivo rush del jazz" (229). En este estudio el texto de Benjamin posee una resonancia especial. Sin embargo, ésta no radica en el encuentro del sujeto con un género musical o el clímax perceptivo que lo acompaña, sino en la posibilidad de discernir, en la sonoridad de los espacios, materiales de construcción que permiten la legibilidad paisajística de la ciudad.

En este sentido, resultan decidores apuntes anteriores al de "Marsella" (1932). En el pasaje "Ruidos" (1928), por ejemplo, Benjamin señala que en "las calles desiertas del barrio portuario, [...] en estos rincones abandonados todos los sonidos y las cosas tienen su silencio propio, así como a la tarde en las alturas existe el silencio de los gallos, el silencio del hacha, el silencio de los grillos" (2011: 86-87). Percibe, como Donoso en sus crónicas urbanas, el silencio del sonido, una irrupción otra que alienta la escucha de pliegues y pausas; gestos e "historias que duermen en las calles y que yacen a veces en un simple nombre, replegadas en ese dedal como las sedas del hada" (De Certeau, 2007: 145). Ahora bien, la imagen que Ramos antepone en el ensayo "Descarga acústica" es similar a la ruptura que sobre el tímpano produce un estallido ensordecedor. Esta fisura es necesaria para que, desde el silencio interno que sobreviene, brote un hambre de sonidos. La confluencia acústica, en principio informe o caótica, encuentra en el oído de José Donoso un canal literario desde el cual se desprende un paisaje urbano silente, pero en ningún caso vacío de expresividad. 
Por el contrario, el paisaje santiaguino advierte un potencial manifiesto en la arquitectura de sus barrios tradicionales que, no obstante, sugieren falta de vigor. En La desesperanza (1986), Donoso ofrece una evolución de algunas áreas icónicas de Santiago, como el barrio Bellavista. Antes de convertirse en centro bohemio, el barrio "parecía sumido en la caquexia anacrónica del olvido" (1986: 24), fatiga que también se observa en otras zonas del poniente. Importa resaltar aquí la imagen de una ciudad que pierde la capacidad de articularse a través de su propia voz. Desde este preámbulo esbozaremos un enfoque al paisaje urbano. Conviene, eso sí, establecer puentes entre imaginarios y cartografías con el fin de explicar este concepto con mayor claridad.

$\mathrm{Al}$ respecto, Lucía Guerra entrega una acotación relevante cuando señala que las experiencias en torno a las ciudades, "insertas en un contexto corporal, social y cultural, crean fracturas y remodelizaciones del espacio urbano dando paso a la imaginación, a otros signos, imágenes y narrativas que configuran otra tipología simbólica, ajena a los nítidos trazos de cartografías e imaginarios hegemónicos" (2014: 24-25). Por su parte, Javier Maderuelo indica que de "la misma manera que el paisaje no es la naturaleza ni el territorio, el 'paisaje urbano' no es la ciudad, ni alguno de sus enclaves significativos, sino la imagen que de ella se destila, bien sea esta individual o colectiva” (2010: 575). Estas imágenes son fundamentales para un paisaje acústico literario que intente alterar las cartografías cartesianas. La figuración de la ciudad en el espacio de las crónicas advierte, entonces, un diseño paisajista afín con una poética donosiana que confía en la innovación de la palabra y en la desarticulación de los tropos convencionales que la oligarquía contemporánea impone sobre la ciudad de Santiago ${ }^{3}$.

Esparcidas en sus escritos referenciales, desde fragmentos de diarios hasta artículos y entrevistas, las reflexiones de Donoso sobre novelar la realidad indican un acto, la transformación, y un instrumento, el artificio. Su escritura está guiada por "la conciencia estética de que todo arte es, en

${ }^{3}$ Esta poética se alinea con una crítica del poder. En efecto, y como plantea Morales, "Donoso apuesta a hacer del relato la forma misma de una larga interrogación sobre el fenómeno de la identidad del sujeto social como un producto de las relaciones de poder. Pero moviéndose narrativamente en una sociedad histórica, la chilena, en su espacio interior, regido por el poder de la clase dominante, la de los 'patrones"' (2008: 21). 
parte artificio: realizar esto, incorporar esta conciencia a la técnica y al contenido del arte, es crear una poética" (1998: 457). Desde esta perspectiva, el paisaje urbano se instancia a través de una poética y una imagen, es decir por medio de una transformación artística del espacio citadino4. Intervención que compromete la labor del escritor, pero también la mirada de su subjetividad y fisicidad. "[S]i el paisaje corresponde a nuestra implicación en el mundo", reflexiona Jean-Marc Besse, "eso quiere decir que no está lejos de nosotros, en el horizonte, sino que [...] nos resulta cercano, estamos en contacto con él, digamos que nos envuelve" (2010: 5). Concluye que el "paisaje es un espacio táctil, antes que óptico" (5). ¿Está de más decir que, incluso antes que óptico, el paisaje comienza a percibirse acústicamente? Una poética sinestésica recomendaría eliminar la sujeción jerárquica implicada en la cronología perceptual, privilegiando la apertura hacia nuevos sentidos. Por otro lado, no es menos cierto que el sonido ha sido interpretado como un registro fantasmático que complementa la performatividad visual. Esto explicaría un fenómeno que advierte en las artes, en los lenguajes simbólicos, y desde luego en las teorías contemporáneas del paisaje, un giro acústico que desajusta entornos y prácticas visualmente naturalizadas (Janus, 2011: 182-185).

El modo en que las crónicas enuncian la ciudad delata este giro, solidarizando con una inclinación del oído hacia subjetividades y lugares que "se dejan escuchar". El sonido, en todo caso, juega escurridizamente en la escritura, sin que su huella se imprima indeleblemente en ninguna parte. Por cierto el sonido metaforiza, llevando más allá el reflejo de las cosas, haciendo que repercutan en otro sitio y con otros significados. Pero también -es en este punto donde surge el atisbo de una síntesis entre espacio acústico, paisaje urbano y subjetividad- el sonido transporta al sujeto en un acto reflexivo que lo torna a sí mismo. Esto es en especial acuciante en un género referencial donde "autor y sujeto de la enunciación (o 'narrador') coinciden” (Morales, 2001: 11). Le hace recordar que su morada nunca estuvo realmente en la ciudad, sino más bien en las imágenes acústicas que esa ciudad acuna en sus oídos. De aquí se desprende el principal objetivo de este trabajo. Indagar, desde la experiencia acústica, la emergencia de un

${ }^{4}$ Sobre este punto, ver en bibliografía "Articulación de una poética para la ciudad enmudecida en las crónicas de José Donoso” (Ferrada Aguilar, 2014). 
paisaje que si bien posee fuertes relaciones con las prácticas de modernización de Santiago, repercute asimismo en la subjetividad del tímpano donosiano. En este tono, quisiéramos determinar hasta qué punto la percepción visual de la ciudad se convierte en preámbulo para su enunciación acústica.

\section{Un paisaje inventariado}

Resulta curioso constatar cómo una crónica centrada en Santiago se desenvuelve en tándem con el imaginario musical bonaerense. En efecto, en "Voz e inventario" (1983) las alusiones a "tangos, poemas y milongas" (1998: 156) generan una atmósfera sonora que permite imaginar casi simultáneamente ambas capitales y escuchar sus registros urbanos, como si se tratase de dos composiciones que impactan el oído con efectos distintos en cada caso. Donoso recuerda sus impresiones en el recital de Susana Rinaldi en el Teatro Odeón, que culminó “con Gracias a la vida de Violeta Parra y una ovación enloquecida que casi se transformó en un acto político” (156). Como sucede con las crónicas del autor, un registro lleva a otro; una cadencia es signo de otras por venir. Así, el residuo acústico más notable para Donoso no es la nota de protesta política encarnada en las canciones. Este clamor es parte de una historia urbana y su tradición es anterior a la crisis que vivía en aquellos años el "país hermano" (156). Lo que esta protesta deja escuchar es una "literatura urbana" en torno al "mito poético de la ciudad de Buenos Aires" y a "un idioma referido a actitudes populares" (156-57). Estos elementos de la composición urbana argentina devienen índices con los que Donoso realiza una crítica de la ciudad de Santiago en los ochenta.

Esta crítica produce surcos en la escritura a partir de los cuales un fenómeno particular se expande, abrazando una tradición, pero también especulando respecto a su porvenir. Los trabajos de Donoso crean inflexiones que encuentran antecedentes en la crónica modernista, y con posterioridad, en las crónicas de Joaquín Edwards Bello. Sin ignorar los rasgos distintivos en sus campos de producción literaria, estas escrituras revelan tergiversaciones de las prácticas urbanas a partir de lecturas paisajistas de la ciudad. Logran, en enunciación cronística, lo que Benjamin efectúa en su crítica de la modernidad parisina: enfatizar las huellas preclaras de los espacios como signos de las opacidades que caracterizan la construcción ideológica 
de la ciudad. Criticar implica así distinguir síntomas de condiciones. Donoso ausculta con detención el cuerpo desalmado, vale decir, despoetizado de la ciudad de Santiago. Luego de exponer las bondades poéticas de Buenos Aires, donde "sus arrabales han creado la tradición de una literatura y de un idioma porteño, y de un mito de la ciudad" (1998: 159), concluye que en "Chile, carecemos del orgullo de nuestro idioma vernáculo, y sin ese orgullo, Santiago parece una ciudad sin alma y sin voz, sin su Susana Rinaldi” (159).

En "El retorno del nativo" (1981), crónica que confronta al sujeto de la enunciación con la metamorfoseada ciudad de Santiago, el paisaje emerge desde una integración en "cuerpo vivido" (Besse, 2010: 4) con los espacios urbanos (Ferrada, 2017: 176-77). "Voz e inventario", en tanto, articula un paisaje acústico a partir de dos subtextos: el concierto de Rinaldi y la lectura de Inventario de una arquitectura anónima (1982), de los arquitectos Cristián Boza y Hernán Duval. Desde estas zonas la escritura perfila un paisaje a través de la metaforización del sonido. El Inventario es un "recorrido arquitectónico por todos esos barrios santiaguinos que podrían haber configurado nuestro 'sur"' (Donoso, 1998: 159). El otro, el Sur borgeano de los arrabales, abre un imaginario desde el cual los viejos barrios del poniente aparecen desprovistos de música y poesía. Destacamos que la atención del cronista se desliza desde un régimen de representación visual del paisaje que el Inventario registra en fotografías de cités, pensiones e iglesias abandonadas- a uno que redunda en alusiones acústicas. Si inicialmente los barrios del poniente se dejan ver, en una instancia posterior, ensordecidos por la falta de un mito poético, estos espacios generan una audición atenta a las variaciones musicales entre nuestro "poniente" y el "sur" trasandino. Por medio de este giro surge un juego comparado donde el cronista ve y escucha el paisaje santiaguino a contraluz de otras ciudades y literaturas.

La transición desde lo visual a lo acústico delata un fenómeno que repercute no solo en la esfera de una crítica del arte o en los enfoques de recepción estética. Es un paso que impacta el empirismo interpretativo y encarece, por tanto, un soporte epistémico y discursivo "que no solo critica el ocularcentrismo, sino que también busca elaborar una filosofía que considere las posibilidades de la escucha" 5 (Janus, 2011: 185). Giro anti-ocular

${ }^{5}$ Traducción nuestra. 
es el nombre de esta declinación. Sobre esta forma de concebir la escucha, en tanto disposición perceptual y umbral ontológico, Nancy advierte las insospechadas resonancias de un cuerpo sensible a sus propios sonidos y al de otros cuerpos. "¿Qué es un ser entregado a la escucha, formado por ella o en ella, que escucha con todo su ser?” (2007: 15) es la pregunta que cruza el cometido anti-ocular del autor. Por su parte, el yo cronístico y la escritura que despliega manifiestan una porosidad dispuesta a oír la ciudad, pero sin perderla de vista.

Varias "vistas" a Santiago dan cuenta de este entrelazamiento perceptual que deriva, a fin de cuentas, en la fisonomía musical de la urbe. Una de las circunstancias que instan la enunciación de la crónica es la lectura del Inventario, es decir el recorrido ocular por un texto que instala la mirada en sus fotografías. Se sugiere así un paisaje que responde al orden ocular no solo en las páginas del Inventario, sino también en las de la crónica, espacio que levanta un segundo paisaje a medida que el libro despierta imágenes alojadas en la subjetividad del cronista. "[A]bandonados o casi, los cités y las pensiones y las esquinas y las iglesias, parecen, justamente anónimas porque no generaron una conciencia de sí, ni un idioma, ni una música ni una poesía” (Donoso, 1998: 159). Esta nueva representación paisajista privilegia, sin desprenderse de la impronta ocular, la fugacidad de los sonidos. De este modo, la relación acústica de Donoso con Santiago, más que articular un espacio "otocéntrico" monótono, instancia un paisaje sinestésico. En lugar del vuelco decisivo de un régimen perceptual a otro, o de un giro anti-ocular, las crónicas acentúan un relieve acústico en una cartografía dominada no solo por registros, sino también por normatividades visuales ${ }^{6}$.

Así, la imagen que representa la apertura de lo acústico como material literario en la construcción paisajista no sería la del giro, al menos no uno radical o irreversible. Sería, más bien, el énfasis, aquello que aparece desde un interior. Esta imagen remite a dos significados complementarios en

${ }^{6}$ Desde otra conceptuación, la emergencia acústica tampoco significa el abandono de lo visual. En efecto, la visibilidad "concierne solo a la vista y se limita a lo evidente, mientras que la visualidad tiene que ver con la idea que nos hacemos de las cosas" (Estrada, 2010: 24). Bajo esta distinción, el espacio acústico proyecta imágenes que no son física u ocularmente visibles, pero sí visuales, es decir potencialmente generadoras de ideas. Así, lo visual abriría surcos necesarios para una aprehensión fenomenológica de los paisajes. 
el desarrollo de nuestras ideas. Primero: los sonidos se vuelven audibles desde un territorio impropio, desde una configuración perceptual regida por una visibilidad en los géneros gráfico-literarios y soportes escriturales asociados a la representación de la ciudad y los sujetos urbanos. El surgimiento de lo acústico revela, entonces, además de un decurso epistémico, una intención táctica que desplaza la estrategia visual, resignificándola en contacto con lo acústico. Circula en este primer sentido una crítica vinculada al pensamiento de Michel De Certeau.

Segundo: lo acústico no ocurre solo como evento supeditado a la materialidad de la urbe, sino que incurre en la subjetividad del autor, habitando la interioridad del habla donosiana. Observamos, además, el cuerpo reverberante (Nancy, 2007: 21) del sujeto, cámara de resonancia que, en efecto, traduce los sonidos en un tono diferente al estrictamente acústico. Así ocurre cuando Donoso reconoce que "ver este libro justo después de Buenos Aires, y encontrar que se llama 'inventario' hace pensar: los lugares no sirven más que para inventariarlos cuando de allí no ha nacido una literatura, una música de alto rango" (161). El cuerpo se convierte en un órgano parturiento (Janus, 2011: 187) que origina, en el caso de la escucha atenta del cronista, una modulación musical de la ciudad. Lo acústico, como el sentimiento que despierta, bien puede entenderse como "una metáfora desarrollada, un símbolo no discursivo que articula lo que es verbalmente inefable, esto es, la lógica de la conciencia misma" (Langer, 1978: 153). En otras palabras, después de repercutir en el oído del escritor, el sonido se metaforiza bajo la forma de una música que sugiere, a su vez, un mito poético y una literatura?.

El paisaje urbano en "Voz e inventario" emerge a través de un tránsito en el que la ciudad aparece visible y acústicamente, para luego volcarse a otras variantes de expresión. Sin duda el paisaje físico se manifiesta en breves catálogos que presentan las imágenes del Inventario: "conventillos, cités, modestas casas en barrios olvidados que la juventud no conoce, portales de Avenida Matta, construcciones art decó y art nouveau" (161). Pero

${ }^{7}$ En su ensayo Nancy insiste en la migración del sonido hacia zonas inconmensurables. "Estar a la escucha es siempre estar a orillas del sentido o en un sentido de borde y extremidad, [el sonido equivale así a] un sentido resonante, en que se presume que lo sensato se encuentra en la resonancia y nada más que en ella” (2007: 20). 
este paisaje objetual, adscrito a un diseño fotográfico legible según los códigos que ofrece un libro impreso, experimenta una alteración cuando la secuencia de imágenes se subjetiviza en la memoria del cronista. Después de nombrar los hitos urbanos, surge una interpretación emotiva y provisional, fuera del campo ocular-céntrico. La crónica se aparta así de las grafías que imponen una comprensión visible de la ciudad. Interesa notar que este desprendimiento se realiza en un soporte escritural adscrito al imperio de la letra. Con todo, la crónica transforma aquellos hitos en "encantadores espacios marginales y calles remotas sin ninguna pretensión, que para mí, por lo menos, que las recuerdo cuando no estaban ahogadas en el smog que tanto parece enorgullecernos como si fuera el mejor signo de civilización, tienen el verdadero carácter santiaguino" (161). Claramente el rigor de la imagen fotográfica deriva en un imaginario que no solo intenta abarcar lo inabarcable mediante "elaboraciones simbólicas" (García Canclini, 2010: 154) o "modelaciones imaginarias del espacio urbano" (Guerra, 2014: 27), sino que permite escuchar la ciudad en tono reminiscente. Se aquilata, en efecto, un paisaje texturizado por el sesgo crítico y estético del escritor, pero también por el pasado y la actualidad que lo constituyen.

"[L]os chilenos, siempre arribistas, creemos poder justificar la ausencia de una vida esencial santiaguina, con libros que ilustran sus 'palacios aristocráticos"' (1998: 161), apunta Donoso. Es precisamente esta ausencia de "palacios belle époque de pacotilla" (160) la que explica la marginalidad de los barrios. Son espacios que subsisten alejados de los proyectos de restauración, evocando por el contrario "una época de creaciones" (160). Entra en juego en la traducción paisajista de estos espacios una singularidad, el "verdadero carácter santiaguino", y rasgos "encantadores” y "remotos”, índices de una irreproducibilidad aurática. Calles y cités configuran un paisaje otro al de las políticas restaurativas del centro de Santiago, con edificios en la Alameda no solo "restaurados, sino iluminados con un despliegue de fuerza eléctrica que hiere los ojos, señalando, exactamente, lo que no tenemos, que es una arquitectura tradicional urbana" (160). Ante esto, la vista encandilada encuentra sosiego en la escucha, mitigando la herida retinal con una voluntad acústica. Bajo este signo, la clausura visual conlleva la exacerbación de un nuevo canal. Mientras la mirada revela ausencias, el aguzamiento del oído donosiano crea un paisaje donde convergen una música, un idioma y una literatura populares. 
Ya al comienzo de la crónica Donoso vincula lo popular con lo propio "de cualquier clase social pero es de todos reconocible, asumido como idioma de la literatura, utilizado con el realismo de un Arlt o un Jorge Asís, o estilizado pero también asumido como un Borges" (1998: 157). En el caso de Santiago, la locuacidad de este paisaje asalta la imaginación del autor, repercutiendo en el oído como una aspiración, pero sin alcanzar una resonancia efectiva en las prácticas cotidianas de la ciudad. No sorprende, entonces, que Donoso concluya que el Inventario, pese a sus méritos, "permanece estático, mudo, científico" (1998: 162) debido a que no "vibra aún con las resonancias de nuestra música y de nuestra poesía que conmueven sus piedras" (162). La ciudad así percibida se asemeja a un diapasón que, en contacto con el mito poético, produce un cromatismo tonal y paisajístico que altera las representaciones homogéneas. "En Chile", admite el autor, "los novelistas no se han ocupado de transformar en espacio de la imaginación, un espacio real: el ogro está en nosotros [...]" (162). No solo Santiago, tampoco otras ciudades chilenas han forjado un espacio literario sólido y robusto como sus cimientos. Observamos en esta coyuntura de la discusión un nuevo desplazamiento. Desde un preámbulo visible la enunciación se desliza a la esfera acústica, en términos de percepción y significación. Lo acústico divaga esta vez hacia una zona metafórica donde el sonido revela un idioma y la expresión literaria que éste encarna. A continuación, seguiremos el curso de esta divagación en "Idioma y retorno".

\section{Idioma y retorno acústico}

"Idioma y retorno" y "El retorno del nativo" son crónicas afines. Publicadas en 1981, enuncian el desgarro que implica el abandono de experiencias cosmopolitas y el reencuentro con una ciudad irreconocible. Bien pudiésemos calificar estos trabajos como "crónicas del retorno". También exponen los hitos que se dejan atrás y que conforman las "sugerencias" (Donoso, 1998: 77) literarias, artísticas y culturales que enuncian un paisaje urbano. Desterritorializado de su lengua, el nativo comienza a interrogar su idioma en una suerte de auscultación ontológica. "[L]as diferencias en el idioma de la calle y de los jóvenes que aún no absorbo del todo son inabordables", concede Donoso, "como tampoco parece fácil absorber el habla blanda y 
como deshuesada de los chilenos, que es como yo hablo, pero allá ya no me oía" (1998: 205). En "Idioma y retorno", el autor insiste en la habilitación del habla. Indica que tal vez "sea más difícil, al regresar al país, volver a aclimatarse al propio idioma que al lugar, ciudad o región: la patria de un escritor es inevitablemente su idioma, y su periplo vital es la búsqueda del que le sea tan propio y cómodo como el rincón habitual al perro viejo, y tan natural" (1998: 212).

Implicancias relevantes surgen de esta escucha interior del idioma. Primero, la interacción de registros, las lenguas foráneas y la vernácula tenderán a distenderse en los recorridos urbanos, motivando la interpretación acústica y paisajista del espacio. Es en esta coalición donde mejor se evidencia la subjetividad en crisis. Ofuscado por la fuga del idioma, el sujeto intenta recuperar, paradojalmente, una voz desde siempre en ciernes y expectante, en continuo devenir. Desde este punto de vista, los esfuerzos del autor se dirigen, más bien, a la creación de un idioma y no a su recuperación. No cabría, entonces, una geografía finita para la germinación del idioma, sino un territorio interior expansivo que Nancy identifica con un cuerpo resonante (2007: 20-22). En el contexto de las crónicas de José Donoso no es necesario ir demasiado lejos para advertir esa resonancia. Surge, precisamente, cada vez que la subjetividad entra en crisis con la búsqueda de un "idioma literario" (Donoso, 1998: 214) constituido, entre otros elementos, por una expresión propia y popular.

En efecto, la subjetividad se ruptura, pero no desde la desintegración del colapso, sino desde una literatura que se territorializa en vínculo con la ciudad de Santiago. Es en la ciudad natal donde el autor comienza a escuchar su propia voz. La "descarga acústica" que Ramos propone nos sitúa ante sonidos localizables externamente, "dislocaciones [que] trastornan la designada economía de los órganos, el ordenamiento jerárquico de los sentidos, el cuadro anatómico del saber" (2015: 229). En la enunciación donosiana, sin embargo, el estallido no es a fuerza una irrupción exterior, sino una conmoción interna desde la cual el cronista compone el idioma literario que recorre su escritura. La ruptura es así constitutiva de un cuerpo poroso y resonante, tal y como la fragmentación acaece en sincronía con la emergencia ontológica del sujeto. $\mathrm{Y}$ es a partir de esta fisura que el sujeto inicia una representación paisajística de la ciudad, alterando los regímenes perceptuales adyacentes. 
Segundo, la creación de un idioma y la percepción acústica de la ciudad se exacerban con el autoexilio. El idioma se vuelve inasible, recordemos, en el marco de constantes viajes, primero a Cataluña, luego a Madrid, regiones en las que el autor se sintió, en términos de su relación con la lengua, "totalmente fuera de ambiente" (Donoso, 1998: 214). Sin embargo, la situación empeora en el país de origen. "[A]l llegar a Chile, encontré que aquí también soy exiliado, y así, está ambición mía [un idioma propio] era una quimera" (215). Este "estar fuera" es esencial, por cuanto provee la perspectiva y focalización necesarias para crear una imagen paisajista de Santiago. No es objetividad lo que esta posición exiliada aporta, sino su anverso: dilación de la escucha en derivas que trasladan al autor a los barrios de infancia y juventud. A diferencia de "Voz e inventario", las expresiones acústicas antes que las arquitectónicas generan no solo el interés del cronista en "El espacio literario" e "Idioma y retorno", sino también una suspensión de las lógicas ocular-céntricas que signan la ciudad. Si en "Voz e inventario" el régimen perceptual que orienta el dibujo paisajista es uno visual en tándem con lo acústico, la enunciación en los trabajos de este apartado apuesta por un énfasis hacia la escucha y el despliegue acústico.

El paisaje santiaguino parece encontrarse a la deriva y sujeto al ensayo que significa consolidar, primero, una voz para el escritor y, luego, un idioma literario para la ciudad. "Paisajear" Santiago desde la audición implica así volver a una reflexión ubicua: la relación de Donoso con la escritura. Uno de los motivos que le hacen volver a Chile es relevante: "quería, de nuevo, como en el comienzo de mi carrera de escritor, escribir en el mismo idioma en que vivía. [...]. Quería vivir y escribir en la misma clave de mi castellano" (1998: 215). Ahora bien, en las crónicas de los ochenta el paisaje se enuncia en tres momentos interrelacionados: "desde el extranjero, con una aproximación ex situ al paisaje chileno, luego cuando el cronista se re-incorpora desorientado a su ciudad natal, y finalmente cuando las impresiones de este re-encuentro se diseminan en el corpus de la escritura" (Ferrada, 2017: 165). Cabe destacar que antes de plasmarse en el corpus cronístico, estas impresiones ya han incursionado en el cuerpo del escritor, dejando huellas de una vivencia directa con la ciudad.

Conceder a la ciudad una fisonomía paisajista pasa por establecer una estética que, en este caso, orienta la enunciación literaria de Santiago. 
Los sonidos urbanos confluyen así en la composición cronística, actuando como recursos expresivos y sensibles más que como materia de indagación. Esta postura es análoga a la de algunos enfoques del campo musical contemporáneo. De acuerdo a Ana María Estrada, uno de los aportes del compositor estadounidense John Cage es resignificar el mundo sonoro "a una práctica artística”, más allá de "preceptos estrictamente musicales" (2010: 19-21). De modo similar, Donoso desactiva las tramas acústicas y las pone al servicio de una escucha subjetivada de la ciudad. Se impone, eso sí, una distinción. Cage y los artistas del grupo experimental Fluxus comparten "el ejercicio de pensar el sonido como materia en sí” (Estrada, 2010: 19). Para Donoso, en cambio, el sonido motiva una crítica de la vida cotidiana y, por cierto, una interpretación paisajista de la ciudad siguiendo un tono acústico. El cronista apunta al potencial metafórico y simbólico que subyace en la materialidad del sonido o en los relieves visuales de la ciudad ${ }^{8}$.

La emergencia del paisaje estará supeditada a que el oyente seleccione, de un espectro de sonidos e imágenes, aquellos que reflejen, por así decirlo, el genius loci asociado no solo a las rúbricas del lugar, sino a su propia disposición anímica. En "Idioma y retorno" el autor admite: "En este país culturalmente remotísimo y aislado -Santiago es la capital con menos cines que cualquiera capital del mundo [...]- probablemente no hay otra manera de sentirse culturalmente rico que hipertrofiando y disfrazando lo propio, que no deja de tener valor siempre que se conserve la perspectiva y la proporción” (1998: 216-17). Afinando críticamente el oído, y a partir de un índice audiovisual, Donoso percibe ecos de una práctica precarizada. En un desplazamiento metonímico, las pocas salas de cine en la ciudad denuncian la condición de la cultura nacional. Curiosamente, la técnica cinematográfica convoca multitud de imágenes sonoras, urbanas y cosmopolitas que acentúan el aislamiento del país. Por otro lado, prevalece en la reflexión de Donoso un imaginario que concibe no solo las provincias

${ }^{8}$ Susanne Langer sostiene que una metáfora "es una idea que a su vez funciona como un símbolo [...]. No es discursiva y por lo tanto no hace un enunciado de la idea que transmite; pero formula una nueva concepción para nuestra aprehensión imaginativa directa” (1978: 151). Sobre este particular, el pensamiento filosófico de Langer es afín con el de Paul Ricoeur, para quien la potencia de la metáfora no radica en su capacidad sustitutiva, o en su destreza retórica, sino en hacer germinar una visión nueva sobre la realidad (1995: 66). 
chilenas, sino también la capital, en perpetuo confinamiento, escindidas del Mundo al instante que prometía el noticiario alemán UFA previo a la proyección de la película.

Ante esta coyuntura, la crítica se dirige a la forma compensatoria con la que se sobrelleva -y sublima- esta precariedad: hipertrofiando lo propio, enmascarando la escasez con "restauraciones" espurias que señalan, "exactamente, lo que no tenemos" (Donoso, 1998: 160). En el plano del idioma literario, esta deformación surge cuando Donoso se ve forzado a "entrecomillar" expresiones populares "como si se tratara de una dicción exótica" (1998: 216), excusando así los giros locales. Los escritores bonaerenses, en cambio, han creado un lenguaje popular que se siente a sus anchas en el tango como en la novela. "Nosotros, por otro lado, al ser populares, al escribir o cantar en lo que queremos hacer pasar por el idioma de la calle o del campo de esta época, nos tenemos que disfrazar [...]" (216), lamenta el autor. La conquista de lo popular en la esfera literaria y cotidiana resulta tan acuciante como establecer una conexión en cuerpo vivido con la ciudad.

En "El retorno del nativo", por ejemplo, Donoso enfatiza la escucha como una de las "prerrogativas del novelista" (1998: 204). El cuerpo se abre a su porosidad, permitiendo que Santiago lo invada y "suscite fantasías" (204). Una de estas fantasías imagina la ciudad, a veces, como una versión degradada del laberinto clásico (207); otras como un cuerpo sin alma y sin voz (159). El paisaje aparece cuando el espacio urbano es apropiado subjetivamente, imaginado y metaforizado en una audición interior. Por lo mismo, una comprensión de las crónicas del retorno en el contexto auditivo debe considerar la complicidad de este "retorno" espacial con sus connotaciones acústicas. El regreso al país implica una adaptación geográfica e idiomática. Comporta, además, intimar con la propia escucha. Obtener retorno sugiere dialogar con la voz cuando ésta sale del cuerpo resonante y adquiere, por así decirlo, otro matiz fuera de la musculatura fónica. Este retorno, a su vez, participa de la articulación de un idioma literario y, a través de éste, el paisaje acústico comienza a insinuarse en la enunciación. Crear una imagen paisajista de Santiago implicaría, por lo tanto, escuchar las repercusiones de la propia voz en contacto con otras subjetividades y espacios urbanos. 


\section{Los barrios bajos de Santiago}

Cuando el cronista se ve contrariado por una descarga acústica que, en lugar de ofrecer vigorosos sonidos para la articulación de un idioma literario, le devuelve ecos "entrecomillados" de un lenguaje popular, decide recorrer "los barrios bajos de Santiago" (2009: 302). Cabe notar que estos barrios no son "bajos" debido a una marginalidad social, aun cuando en el presente se describan como "una especie de isla en otro tiempo opulenta que se va deteriorando tranquilamente en el centro de Santiago" (302). Son bajos en virtud de representar un área fundacional en el siglo XIX, y desde la cual el centro de la ciudad se fue extendiendo hasta llegar a las zonas "altas", próximas a la cordillera. Estos barrios son parientes de "la gran burguesía y la clase media que vivían en Dieciocho y Ejército y Avenida España y República, que asistía a los paseos de la Plaza Brasil porque en sus alrededores tenían sus casas de galerías" (302-03).

El sentimiento de exilio en el propio idioma que interpretamos como la oclusión de un retorno acústico, o la incapacidad de escucharse, conmina a José Donoso a "recorrer minuciosamente" (302) los espacios que consolidaron una imagen de la casa paterna y la ciudad natal en su infancia. En "Los barrios bajos de Santiago" el paisaje emerge, al igual que en "Voz e inventario", bajo la confluencia de regímenes perceptuales locomotores, visuales y acústicos. Es posible apreciar, también, una triangulación de estas formas sensibles que, en principio, tienden a fusionarse sinestésicamente sin que ninguna ignore las otras. Un énfasis inicial recae en la visibilidad de las construcciones y objetos que pueblan el espacio:

pensiones de mala muerte, $[\ldots]$ casas renovadas por medio de una mano de pintura chillona tan distinta a los atuendos grises y ocres de entonces, [...] tienduchas en las esquinas donde el gato dormita encima de los periódicos del pequeño mostrador, papel destinado a envolver una ma-

${ }^{9}$ Más extensa que las anteriores, esta crónica consta de dos partes: una con el sobretítulo "Las encamadas (1)" y otra, una especie de continuación, "De mis tías, la más bella", con el sobretítulo "Las camadas (2)". Esta crónica se publica en el Excélsior de México el 5 de julio de 1982, en el suplemento de cultura y finanzas. En José Donoso. Diarios, ensayos, crónicas. 
rraqueta de pan, una carretilla de hilo, una medida de yerba mate para los pocos que ahora tomen mate con azúcar tostada sobre los carbones de un brasero (2009: 302).

Como bien señala el autor, esta escena corresponde a "pintoresquismos de otra época" (302) que revelan un paisaje igualmente "pintoresco", vale decir sujeto a cualidades plásticas y lumínicas que tipifican un lugar y lo vuelven "representable". El carácter visible de la composición da paso a la visualidad, condición que suscita las ideas que nos hacemos del mundo (Estrada, 2010: 24-25). Desde este ángulo, lo visual en tanto visualización o, mejor, imaginación, se encontraría mucho más próximo a la actividad acústica que a la ocular. Pasamos, entonces, de una percepción sensible a otra fenoménica con una fuerte orientación crítica: "Esta modestia, por no decir pobreza e incluso miseria, distinta a las bullentes poblaciones obreras de más al oriente y al norte y al sur, es hoy la contradicción misma de las multinacionales de acero y cristal, y de los shopping centers del Barrio Alto [...]” (Donoso, 2009: 302).

Bajo este signo, la enunciación en las crónicas de José Donoso se desprende gradualmente del paisaje visible y se centra, diríamos, en su "repercusión" visual. Reiteramos que este modo visible no desaparece. Se desplaza hacia una región ensombrecida desde la cual continúa aportando vívidas imágenes que se conectan con las acústicas. La alternancia de los regímenes perceptuales sugiere así, como explica acertadamente el musicólogo Peter Szendy, "una sobrepuja infinita, pero siempre orientada hacia el horizonte del recogimiento, el ojo y el oído se relevan uno a otro en vista de la unidad que se espera" (2015: 85). En nuestro estudio, esta unidad instancia una condensación sinestética y, desde aquí, un paisaje adscrito a la evocación sensible de Santiago a través de una audición atenta a los ecos de prácticas y subjetividades citadinas. Esta visión imaginativa comporta una interpretación subjetivada de lo que el cronista observa: ya no son las presencias físico-oculares las que fundamentan la construcción del paisaje, sino las imágenes que ellas proyectan en la escritura cronística.

Las pensiones, calles y tiendas que despiertan interés debido a rasgos pintorescos y anacrónicos, se convierten en preámbulo para una crítica de la vida cotidiana. Crítica que, conviene señalar, califica las poblaciones nuevas de "bullentes", atraídas por el movimiento y la agitación, diametral- 
mente opuestas al deterioro de los barrios bajos. Este decaimiento apunta al colapso de los valores de una clase burguesa, a la desaparición de un mundo que el autor ya advirtiera en Coronación (1957) y Este domingo (1966). Valores, o condición de mundo, que sugieren también la degradación de los mitos fundantes de una clase social ${ }^{10}$. Más que una forma de modernización, lo que lamenta el autor es la retirada de esos valores, la imposibilidad de enriquecer su relación con la ciudad de Santiago que "tan porfiadamente se me escapa de las manos" (2009: 302). Donoso se confronta así con un paisaje que recuerda su infancia en "una profunda casa crepuscular de tres patios en calle Ejército" (2009: 303). Rodearon esta edad la sensualidad de "confites de nombres olvidados puestos a enfriar en el mármol enmantequillado" (303), junto a los sonidos piadosos "en el oratorio de la casa resonante de novenas y rosarios; y repleta de los cuchicheos de las criadas" (303). Santiago comienza a escucharse e imaginarse desde la casa, espacio genealógico por excelencia. La mirada y la escucha recorren la ciudad a partir de esta cota cero, y desde la cual surge un imaginario extramuros que incluye ficciones y textos referenciales como la crónica referida aquí ${ }^{11}$.

La casa motiva la salida al exterior, pero también un viaje interiorizado a través del recuerdo. En una de estas casas del barrio bajo vivía "la tía Clarisa entre sus sábanas bordadas de hilo, [...] el símbolo de ese mundo que veo "encamado" (Donoso, 2009: 299). Tanto la casa como la anciana evocan sonidos de otra época, registros acústicos de un tiempo cuya vitalidad se desvanece, dejando en el tímpano del cronista ecos que se mezclan con las "casas de vidrios polvorientos y mamparas trizadas" (2009: 303) a medida que transita las calles Dieciocho, Ejército y República. "De mis tías, la más bella” actúa como continuación y coda de "Los barrios bajos de San-

${ }^{10}$ En La novela chilena. Los mitos degradados (1968) Cedomil Goic explica cómo José Donoso se distancia no solo de una poética realista, sino también de epistemes inoperantes al momento de representar las fisuras del sujeto.

${ }^{11}$ El cuento “China”, publicado por primera vez en 1954, es paradigmático: subraya la emergencia de la subjetividad infantil entre el espacio doméstico y el urbano. Imaginación e imaginario interactúan en el surgimiento del paisaje. Rodríguez y Burich acentúan la minucia y su función en el disciplinamiento de los cuerpos en "La anatomía del detalle en 'China' de José Donoso" (2013). Este estudio permitiría indagar el efecto de los detalles acústicos en la construcción del paisaje, ofreciendo una resistencia al imperio del ojo. 
tiago", acentuando la reverberación de un recorrido acústico que se inicia con "Idioma y retorno" y "Voz e inventario".

Los sonidos repercuten en la escucha ávida del escritor y, en perspectiva, podemos incluso advertir un trazo, una dirección. En un primer momento, semejante al de una obertura, el sonido irrumpe y se amplifica en el paisaje laberíntico de la ciudad; se vuelve audible gracias a la materialidad de los volúmenes circundantes y, por cierto, a la disposición sensible del cronista. Es lo que sucede cuando Donoso oye en las calles del centro frases que le parecen ajenas, mezcladas con "insoportables y ubicuos diminutivos" (1998: 215). El habla de los chilenos, "blanda y como deshuesada" (1998: 205), le devuelve una imagen de su propia voz que en el extranjero no percibía. Es decir, los sonidos de la voz propician la subjetivación reflexiva del escritor. El cronista comienza a escucharse desde esta apertura que, como su nombre indica, inaugura el diseño de un paisaje animado por elementos acústicos en las crónicas del retorno ${ }^{12}$.

En las crónicas inspiradas en los barrios bajos, en cambio, los sonidos se perciben desde una perspectiva panorámica y abierta en el centro de Santiago, y siguen su curso hasta reverberar en los barrios con un signo e intensidad diferentes. Los sonidos contingentes, sujetos a prácticas y subjetividades contemporáneas, dan paso a un repertorio acústico extemporáneo. El habla deshuesada en los espacios públicos cede protagonismo y, por medio de una écfrasis que recrea el ambiente sonoro en la memoria del cronista, se representan las conversaciones, susurros y melodías que animaron el espacio íntimo de la habitación de una "encamada". Donoso recuerda que la tía Clarisa compró "una radio Telefunken negra, y le regaló otra igual a mis padres. A los pocos días tuvimos que cambiar la nuestra por la suya porque, dijo 'la de ustedes tiene piezas más lindas que la mía, como si se tratara de cajitas de música” (2009, p. 299). La habitación, la calle y el barrio participan de un entramado paisajista donde dejan de subordinarse espacial o arquitectónicamente. Dialogan a partir de una lengua franca, la

12 "Música condenada a morir" es un trabajo que, desde un punto de vista temporal, merecería con mayor propiedad iniciar esta genealogía. Publicada en 1963 y reunida por Cecilia García Huidobro en El escribidor intruso (2004), esta crónica narra el precario mundo de los organilleros cuyo arte irrumpe en esquinas y plazas. Nuestro estudio, sin embargo, enfatiza la emergencia de un paisaje acústico en un momento crítico de enunciación: el retorno definitivo de José Donoso a Santiago a inicios de los ochenta. 
acústica, y a través de la cual apreciamos la visualidad o carga connotativa de cada uno de esos hitos, los cuales comportan alusiones e imágenes en un in crescendo musical. Al enunciar la crónica desde la casa y la habitación, Donoso recuerda a un visitante de la encamada, Luis Arrieta, "en cuya casa ella estuvo cuando por primera vez se ejecutó la música de Wagner en Chile, y hablaban de otros tiempos-como yo estoy comenzando a hacerlo ahora-, y de óperas, y de trasatlánticos, y de gente desaparecida” (299).

Protagoniza esta crónica un tono de pérdida. La Segunda Guerra Mundial, junto con la vejez de la tía, señala locuazmente la retirada de un mundo que antaño prodigara certeza y estabilidad. "[C]uando sonaban esas voces terribles [anunciando por radio el inminente conflicto bélico], ella cambiaba la estación, buscaba, sin encontrar, las melodías que a ella le gustaban... 'La Nonette de Portici', 'Dinorah', 'Chiribirin', 'El Carnaval de Venecia'...” (299). El cronista, por su parte, también "cambia de estación". Cuando sus andares por el barrio de Providencia y el centro de Santiago le hacen sentir que la ciudad se convierte en un inventario carente de mito poético, opta por "el trabajo de ir, como en un peregrinaje a otra ciudad que encierra el pasado, el Barrio Bajo” (299). Sin embargo, y al igual que su tía encamada, en esta sección antigua de la ciudad tampoco encuentra las melodías deseadas. Con la alusión a "la petite madeleine proustiana" (2009: 303) en "Los barrios bajos de Santiago", estos registros metaforizan el deseo de volver a escuchar un tiempo perdido, de "reencontrar el mundo estático del tiempo de mi niñez" (304). Después del recuerdo a través de una escucha que busca ávida imágenes acústicas, permanece en el tímpano literario de José Donoso el eco de una desaparición que, a su vez, hace visible la emergencia de un paisaje "extraño, exótico y encamado, que nuestros hijos no conocen, y donde casi no se atreven a ir" (2009: 298).

\section{Conclusiones provisionales}

Nos parece relevante iterar que la transición de lo ocular a lo acústico no solo repercute en la esfera de una crítica "descentrada” del arte. Conlleva, además, implicancias en la esfera del empirismo interpretativo. Hace que el investigador recurra a tácticas y decursos (De Certeau, 2007: 40-45) que, en nuestro caso, permiten explorar el paisaje urbano en la tesitura de la 
escritura cronística. Más aún si este paisaje se desliza desde un ámbito especular a otro acústico donde los sonidos no obedecen direcciones físicas, sino a trayectorias que atraviesan la subjetividad del cronista, suscitando impresiones e imágenes. Una indagación que desestime los contenidos subjetivos e impremeditados de las construcciones paisajistas posiblemente logre un cometido parcial. Bajo un enfoque contemporáneo, el paisaje emerge fruto de una interpretación subjetivada, e incluso emotiva, del entorno. Convocado por las facultades estéticas y creativas del sujeto, el paisaje se manifiesta desde una interioridad que posterga la visibilidad que imponen, por ejemplo, el territorio o la geografía. Es por esto que en este estudio nos hemos adentrado en el ámbito del paisaje urbano a partir del umbral de una escucha, que actúa, por cierto, como canal perceptual, pero principalmente como instrumento epistémico que altera la representación y la imagen misma del paisaje.

Quizás debamos a la tradición de la pintura paisajística -que evoluciona en estrecho vínculo con la cultura ocularcéntrica- una técnica que nos enseñó a interpretar los paisajes descritos en la literatura, y que consistiría en restituirlos nuevamente al ámbito plástico, leyéndolos "como si fueran cuadros". Sin embargo, toda pedagogía presenta yerros. Esta práctica no solo vuelve a encarecer el dominio ocular en un espacio escritural que sobrepasa y supera lo visible, sino que anula la posibilidad de apreciar los paisajes en términos literarios, es decir en tanto metáforas, figuraciones, simbolizaciones. Permanecer fieles al curso de esta pedagogía nos hubiese obligado a ignorar el potencial paisajístico que se ciñe alrededor y dentro de una habitación en un barrio santiaguino. Con frecuencia encontramos expresiones que, refiriéndose al trabajo plástico de un artista, señalan que éste "es un pintor de exteriores, de paisajes". Equiparar el entorno exterior "natural" con la noción de paisaje se ha convertido en un lugar común y, por lo mismo, resulta extraño concebir casas y cuartos de ancianas encamadas como elementos de la construcción paisajista. ¿̇Pero no es acaso al interior de estos recintos donde el paisaje santiaguino se vuelve acústicamente perceptible, tanto para Donoso como sus lectores? ¿Y no es sino desde el recuerdo que el autor escucha sonidos pretéritos que repercuten en el presente de la enunciación cronística?

Este estudio ha acentuado la tensión del giro acústico en la aprehensión del paisaje, vale decir un soporte epistémico donde la objetivación visible 
de Santiago da paso a su subjetivación en el tejido de las crónicas de José Donoso. Este proceso esta mediado por una percepción paisajista del espacio urbano donde intervienen aportes imaginativos -las "prerrogativas del novelista” (Donoso, 1998: 204) - como también una audición fenoménica del entorno. Tanto la visibilidad de una ciudad desmesurada y laberíntica como la percepción fisiológica de sus estímulos sonoros instancian la emergencia de un paisaje acústico. Participa en esta obra "esa 'fantasía' de la que los chilenos tanto desconfiamos" (1998: 210-11), recurso prioritario en la enunciación de Santiago y que, en solidaridad con una memoria emotiva, transporta al cronista a los pliegues de la casa de infancia. Esta casa, como señalamos, es parte de una composición paisajista arraigada a la experiencia de un barrio bajo que “se ha ‘encamado' para esperar la muerte, pero que es sin duda la escenografía, conservada como con la perfección de Pompeya, bajo el polvo del tiempo, de un modo de vida, más modesto y menos pretensioso, pero a la vez muy nuestro, que se ha desvanecido..." (1998: 298).

Constatamos, así, que la figuración de un régimen acústico en las crónicas promueve un paisaje animado en el pasado por una plétora de registros sonoros, que van desde el susurro de oraciones y el trajín doméstico en la casa de tres patios, hasta una musicalidad que adopta, a su vez, múltiples variaciones. En "Voz e inventario" esta modulación confirma un mito poético y un idioma popular, pivotes de una literatura urbana que Donoso advierte debilitados en Santiago. En "Los barrios bajos de Santiago" y su coda, "De mis tías, la más bella", estos sonidos se encarnan efectivamente en piezas musicales que, con certeza, introdujeron al niño en un repertorio acústico inédito y, tal como sugiere la crónica, memorable. Estas melodías sedimentan en la memoria recuerdos preciados e indelebles, que repercuten nuevamente a inicios de los ochenta ante el reconocimiento de que no solo el barrio bajo ha enmudecido encamado, sino toda la ciudad y, con ella, la visión de un mundo resguardado.

\section{Referencias}

Benjamin, W. (1989). Discursos interrumpidos I. Madrid: Taurus. Plata. . (2011). Denkbilder. Epifanías en viajes. Buenos Aires: El Cuenco de 
Besse, J-M. (2006). "Ensayo de una cartografía de las problemáticas paisajeras contemporáneas”. Paisaje y pensamiento. Madrid: Abada, 145-171. . (2010). "El espacio del paisaje". III Jornadas del Doctorado en Geografía. La Plata, Argentina. http://www.memoria.fahce.unlp.edu.ar/trab_ eventos/ev.1488/ev.1488.pdf.

Boza, C. y Duval, H. (1982). Inventario de una arquitectura anónima. Santiago: Lord Cochrane.

Catalán, P. (2004). Cartografía de José Donoso. Santiago: Frasis.

De Certeau, M. (2007). La invención de lo cotidiano I. México, D. F.: Universidad Iberoamericana.

De Nordenflycht, A. y Doll, D. (eds.) (2009). Ciudades (in)ciertas. Valparaíso: Puerto de Escape.

Donoso, J. (1985). Cuentos. Santiago: Seix Barral. . (1986). La desesperanza. Barcelona: Seix Barral. . (1998). Artículos de incierta necesidad. Ed. Cecilia García Huidobro. Santiago: Alfaguara. . (2004). El escribidor intruso. Artículos, crónicas y entrevistas. Ed. Cecilia García Huidobro. Santiago: Ediciones Universidad Diego Portales. . (2009). José Donoso. Diarios, ensayos, crónicas. Ed. Patricia Rubio. Santiago: RIL.

Estrada, A. M. (2010). "Para una comprensión estética de la conformación del Arte Sonoro". Sonidos Visibles. Antecedentes y desarrollo del arte sonoro en Chile (pp. 11-34). Santiago: Mosquito Comunicaciones.

Ferrada Aguilar, A. (2014). "Articulación de una poética para la ciudad enmudecida en las crónicas de José Donoso", Revista Chilena de Literatura, 87, $115-138$.

. (2017). "El paisaje como cuerpo vivido en las crónicas de José Donoso". Revista Chilena de Literatura, 96, 163-185.

García Canclini, N. (2010). Imaginarios urbanos. Buenos Aires: Eudeba.

Goić, C. (1968). La novela chilena. Los mitos degradados. Santiago: Editorial Universitaria.

Guerra, L. (2014). Ciudad, género e imaginarios urbanos en la narrativa latinoamericana. Santiago: Cuarto Propio.

Janus, A. (2011). "Listening: Jean-Luc Nancy and the 'Anti-Ocular' Turn in Continental Philosophy and Critical Theory". Comparative Literature, 63(2), 182-202.

Langer, S. (1978). "La obra artística como forma expresiva”. Antología. Textos de estética y teoría del arte (145-53). México D. F.: UNAM.

Llorente, M. (2014). "La ciudad representada: espacio habitado y literatura urbana”. Topología del espacio urbano. Palabras, imágenes y experiencias que definen la ciudad (171-211). Madrid: Abada. 
Maderuelo, J. (2010). "El paisaje urbano". Estudios Geográficos, Vol. LXXI, 575-600.

Martínez de Pisón, E. (2009). Miradas sobre el paisaje. Madrid: Biblioteca Nueva.

Milani, R. (2007). El arte del paisaje. Madrid: Biblioteca Nueva.

Morales, L. (2001). La escritura de al lado. Géneros referenciales. Santiago: Cuarto Propio.

. (2008). De muertos y sobrevivientes. Narración chilena moderna. Santiago: Cuarto Propio.

Nancy, J-L. (2007). A la escucha. Buenos Aires: Amorrortu.

Nogué, J. (2007). “La construcción social de los paisajes urbanos”. La construcción social del paisaje (163-313). Madrid: Biblioteca Nueva.

Ramos, J. (2015). "Descarga acústica". Latinoamericanismo a contrapelo (229-256). Popayán: Universidad del Cauca.

Ricoeur, P. (1995). Teoría de la interpretación. México, D.F.: Siglo XXI.

Rodríguez, M. y Burich, Y. (2013). "La anatomía del detalle en 'China' de José Donoso". Estudios Filológicos, 52, 117-127.

Schafer, M. R. (1994). The Soundscape: Our Sonic Environment and the Tuning of the World. Rochester: World Destiny Books.

Schoennenbeck, S. (2015). José Donoso. Paisajes, rutas y fugas. Santiago: Orjikh.

Solnit, R. (2015). Wonderlust. Una historia del caminar. Madrid: Capitán Swing.

Szendy, P. (2015). En lo profundo de un oído. Una estética de la escucha. Santiago: Metales Pesados.

Urquijo, P. y Barrera, N. (2009). "Historia y paisaje. Explorando un concepto geográfico monista”. Andamios. Revista de Investigación Social, 10, 227252. 